\title{
What Are The Factors Affecting No-Till Adoption In The Farming System Of Sétif Province In Algeria?
}

\author{
Amar Rouabhi ${ }^{12^{*}}$, Abdelmalek Laouar ${ }^{1}$, Abdelhamid Mekhlouf ${ }^{1}$, Boubaker Dhehibi $^{3}$ \\ ${ }^{1}$ Department of Agronomy, University of Ferhat ABBAS, Sétifl, Algeria \\ ${ }^{2}$ Laboratoire d'Amélioration et de Développement de la Production Animale et Végétale \\ ${ }^{3}$ ICARDA, P.O. Box 950764, $N^{\circ}$ 11195, Amman, Jordan
}

A R T I C LE IN F O A B S T R A C T

\section{Research Article}

Received 20 May 2017

Accepted 21 March 2018

Keywords:

No-till

Conservation agriculture

Semi-arid

Sétif

Algeria

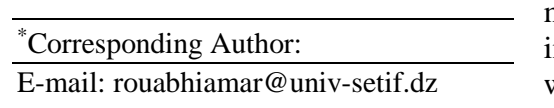

DOI: https://doi.org/10.24925/turjaf.v6i6.636-641.1343
Conservation agriculture is a concept which defines different farming systems. Its implementation depends on soil properties, climate and socio-economic considerations. Since two thousands, no-till technology; which is one facet of the conservation agriculture has begun to take place in the high plains of Sétif province-Algeria. Its adoption is facing several problems of socio-economic and technical issues. This work monitored the track of no-till adoption within a sample of 28 farmers during two years 2014 and 2016. During 2014 farmers were supported financially and technically through a subsidy program that aimed at the support of conservation agriculture via no-till technique. In 2016, the subsidy program has ended; hence, farmers have no longer incentives. Multivariate statistical analyses were performed to diagnose the evolution of no-till adoption and behavior's farmers between the two periods. In 2016, results showed an increase of no-till area, even though, the drop of the number of adoptive farmers by $71 \%$. The main reasons for adopting no-till according to the adoptive farmers were the minimization of farming operation costs and saving time. However, the major impediments facing no-till adoption; were the rise of weeding charges and the concern of weed infestation especially by bromus.sp, which is a vigorous prevalent weed, which locally developed some pesticide's resistance. Also, the excessive use of pesticides may be considered as an environmental reason for no adopting no-till.

\section{Introduction}

Conventional agriculture based on intensive land use and fallowing has shown limitations, resulting in soil degradation and stagnant yields. Indeed, the mechanized work of the soil has led to fragmentation, soil compaction, organic matter depletion and erosion. (Boiffin et al., 2001, Mrabet, 2001, Chervet et al., 2005, Mrabet, 2010). Conservation agriculture has emerged as an alternative to conventional agriculture, to ensure yield regularity and to protect soil and water resources against erosion and evapotranspiration in bioclimatic areas where rainfall is scarce and irregular (Ben-Salem et al, 2006; Masmoudi, 2012). Simplified cropping techniques and no-till or "Direct seeding" are two facets of conservation agriculture. They can better control erosion, store organic matter, improve water efficiency and restructure the soil through better biological activity (Mrabet, 2000). In notill cropping, farmers use a specific seeder machine, by creating a narrow furrow, just large enough for the crop's seeds to be injected, without turning soil. Furthermore, fertilizer is injected with the seeds without the need to fertilize the whole field and close up the furrow after the seed and fertilizer have been planted. With this method, the soil can be seeded with minimal disturbance. This technique deserves to be studied better in the agroclimatic context before deciding on their adoption by the professionals. (Carof, 2006; Zaghouane et al., 2006; Labreuche et al., 2007). It is also perceived as an alternative solution for the climatic constraint, through its virtues in improving the capacity of water storage and the coverage of mulch which limits evapotranspiration. However, no-till technology could face some of socioeconomic and technical constraints such as the high cost of machinery, trust of farmers and weed control.

This work aimed at diagnosing the adoption of the notill technique during and after the end of financial and technical support provided by the subsidy program. The latter spanned between 2014 and 2016. It aimed at the popularization and the extension of conservation agriculture among local farmers. The survey focused on the trends of no-till adoption and factors that influenced farmers to keep or abandon this technique. Furthermore, the study attempted to highlight the principal emerging constraints during the lifetime of the survey. 


\section{Materials and methods}

\section{The Region of The Study}

Sétif province is situated in the east of Algeria; it is characterized by a continental climate, belonging to the semi-arid bioclimatic stage (Labad and Hartani, 2016). Soils are calcareous with medium to low fertility and sensitive to erosion. The local farming system is mainly mixed smallholder based on the combination of cereal crops and ovine breeding (Rouabhi, 2014).

The study area is located in the central part of the Sétif province; it occupies an area of $1.502 \mathrm{~km}^{2}$, characterized by a marked north-south rainfall gradient, ranging from $250 \mathrm{~mm}$ to $500 \mathrm{~mm}$ (Rouabhi, 2014). The surveyed farms are spread over 10 municipalities namely: Ä̈n Oulmene, Ksar El Abtal, Bir Hadada, Guellal, Guidjel, Mezloug, Ain Arnat, Sétif, El Ouricia and Beni Fouda (Fig. 1).

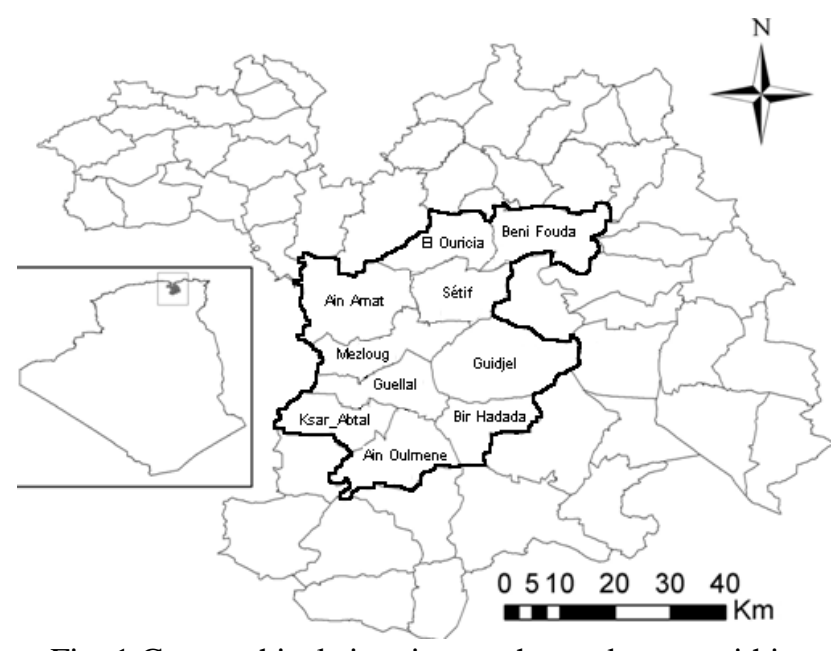

Fig. 1 Geographical situation on the study area within Sétif province

\section{Sampling and Data Processing}

In this study, a targeted sampling method was used; concerning a set of 28 farmers. The sample met some of technical and organizational criteria that allowed The Technical Institute of Cereals (ITGC-Sétif) to monitor the different steps of subsidy program. Throughout the participative approach, the ITGC played a crucial role in popularizing this technique and sensitizing farmers by granting them technical and financial aids. Farmers were belonged to different climatic stages, mainly practicing cereals as a staple activity and characterized by small scale farming.

The survey was conducted twice, during 2014 and 2016, implicating a tracked sample of farmers involved in the no-till adoption process. It included a series of questions directly addressed to farmers in a face to face questionnaire in order to collect information according to:

- $\quad$-Socio-economic data

- $\quad$-Plant and animal production

- Water resources

- Practice of no-till

- The constraints and advantages of adopting no-till

- Reasons for adopting and/or abandoning no-till.
The statistical analysis focused on descriptive treatments of the socio-economic and biophysical skills of the farms. Further the classification methods as the Twostep analysis and multivariate analyses as the Categorical Principle Component Analysis (CatPCA) and the Multiple Correspondence Analysis (MCA) were performed to characterize and discuss the reasons governing no-till adoption. Microsoft Excel and SPSS V18 were used in the processing of data.

\section{Results and discussion}

\section{The Socio-Economic Skills of Farms}

Monitoring of the socio-economic component focused on endogenous farming criteria describing the quality of farmers namely: the age, educational level and technical level of agricultural training.

\section{Age of Farmer}

The average age of surveyed farmers was 51 years. The majority of farmers were elderly where almost of $54 \%$ were older than 50 years. This finding corroborates the results of the general census of agriculture in 2001, stating that the age of farmers at the national level is considerably high. However, the minimum age in the sample was 32 years, while the maximum age was 66 years.

\section{Level of Education}

The results showed that the level of education of farmers is significantly high, where $39 \%$ and $25 \%$ respectively represented the secondary and the university level. This result is contrary to the figures put forward by Rouabhi (2014) saying that the level of education of local farmers is largely low. This contrast could be due to the targeted sampling method used in this study. Zoghbi (1992) pointed out that low level of education is a major impediment to agricultural development.

\section{The Technical Level in Agricultural Training}

Accordingly, to the educational level, the observed level of agricultural technical training was relatively high. Where $39 \%$ had a very good technical level, however, $36 \%$ had a medium level and $25 \%$ had low skills. In Algeria, the role of agricultural training centers in developing skills and training farmers is very limited. Berranen (2007) highlighted that only $1 \%$ of the total number of farmers has been concerned by training between 2000 and 2006. In the local farming system, the low level of education and the lack of agricultural training are the most important obstacles for the development of agricultural know-how.

\section{The Economic Performance of Farm}

Economic performance (EP) is a measure of the ability of the farm to generate economic and financial profits during its annual activity. Each farmer evaluates the EP of his farm by a score ranging from 0 to 10 , which is the case of a Likert scale. A farm is considered good if its EP is greater than or equal to $7 / 10$; whereas it is economically fair if its EP is between 4 and 6, while it is considered weak, if the score is less than or equal to $4 / 10$. Results showed that more than $86 \%$ of farms have good and fair EP (Table 1). However, the overall average of EP is $6.25 / 10$. 
Table 1 Economic Performance of surveyed farms

\begin{tabular}{l|cc}
\multicolumn{1}{c|}{ Modality } & scale of EP & Number of farms \\
\hline Good & $\mathrm{EP} \geq 7$ & 15 \\
Fair & $4<\mathrm{EP}<6$ & 9 \\
Weak & $\mathrm{EP} \leq 4$ & 4 \\
\hline
\end{tabular}

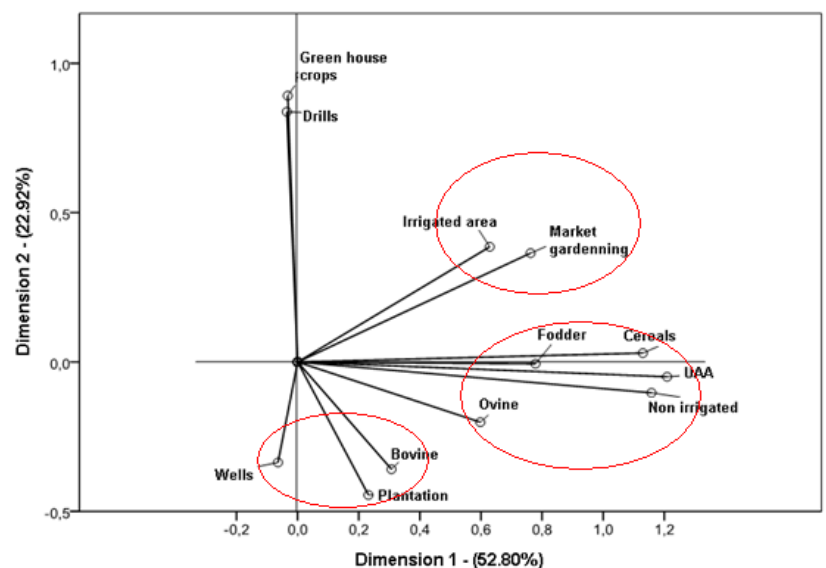

Fig. 2 Different typologies observed in the study area

\begin{tabular}{|l|c|c|c|}
\hline Cluster & $\mathbf{1}$ & $\mathbf{3}$ & $\mathbf{2}$ \\
\cline { 2 - 4 } Description & $\begin{array}{l}\text { Small scale (55.6\%) } \\
\text { Mean UAA:27.28ha }\end{array}$ & $\begin{array}{l}\text { Medium scale(29.6\%) } \\
\text { Mean UAA:64.13ha }\end{array}$ & $\begin{array}{l}\text { Large scale (14.8\%) } \\
\text { Mean UAA:102ha }\end{array}$ \\
\hline Distributions & UAA & UAA & UAA \\
& &
\end{tabular}

Fig. 3 Clustering of Utilized Agricultural Area (UAA)

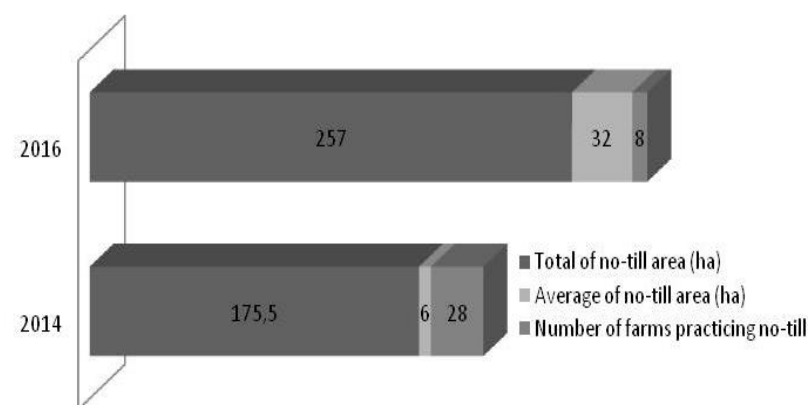

Fig. 4 Evolution of the total area of no-till, the average area of no-till and the number of farmers adopting no-till within the sample between 2014 and 2016

\section{The Physical Structure of Farms}

Animal productions: The results of livestock production showed that breeding activities are mainly based on sheep farming followed by cattle breeding. For farms practicing sheep breeding, the average number of sheep was 272 heads; this figure implicated high agro pastoral skills. However, farms practicing cattle breeding had an average of 6 heads; this relatively low figure indicated that a cattle breeding is a secondary activity. As regards apiculture and poultry farming, number of farms practicing these activities was too low; it was about two farms only. As a result, it can be said that the general typology of farms does not revolve around animal activities except sheep farming, which is often combined with the activity of cereals and which represents a vital dimension of our local agriculture (Houmoura and Sebaoune, 2014). In addition, Escribano, (2006) considers that the integration of grain and livestock production activities improves the economic stability of farms and makes them more protected from market risks.

Plant production: In Algeria, cereal products occupied a strategic role in food security of the national economy (Djermoun, 2009). Given the general typology of farms, cereals and fodder crops are taking up the majority of the areas, as mentioned by Rouabhi et al (2016) in the south part of Sétif province. Cereal crops recorded an average of 110 ha per farm, whereas fodder crops recorded an average of 11 ha. The area of market gardening recorded an average of $12 \mathrm{ha}$. However, plantation area indicated a mean of 12ha. Among the sample, there are 5 farms practicing greenhouse crops, with an average of 26 greenhouses, this figure is relatively high and characterized farms of the southern part of Sétif province as demonstrated by Mokhnache and Elkolli (2013).

Typologies of farms: The factorial map resulting from the CatPCA suggested the formation of three typologies according to the most discriminating variables. The first axis explained $52.80 \%$ of the total inertia (Fig. 2), recording high loadings in relation to the variables characterizing farm size and rainfed activities, such as Utilized Agricultural Area (UAA), cereals and fodder crops. While the second axis represented $22.92 \%$ of the total inertia, it symbolized the irrigated crops and breeding activities namely market gardening, plantation and bovine breeding (Fig. 2).

Clustering farms according to the Utilized Agricultural Area (UAA): UAA classification is an important criterion to know farm potentials and to understand choices of farmers. The Two-Step classification was used to classify farms on the basis of UAA into three separate homogeneous clusters. Results showed the formation of three groups with a good pattern of separation. The first group characterized the "small scale farming" including $55.6 \%$ of farms, with an average UAA of 27.28ha, while the "medium scale farming" occupied $29.6 \%$ of farms with an average UAA of $64.13 \mathrm{ha}$. The "large scale farming" represented $14.8 \%$ of the total number of farms with a mean of 102ha. (Fig. 3). This finding corroborates the results obtained by Rouabhi et al., (2014) for the northern region of Sétif.

\section{No-till Adoption Patterns}

Total area of no-till and number of farmers: Between the two periods, no-till area showed an increase of 82ha, rising from 175.5 ha to 257 ha (Fig. 4). However, the number of farmers practicing no-till decreased drastically from 28 to 8 farmers. On the other hand, the average area of no-till in the farms that preserved no-till has increased considerably, rising from 6.26 ha in 2014 to 32.12 ha in 2016. Due to the completion of the subsidy program, the abundant farmers are unable to pursue no-till practice either for financial or technical reasons. As the success of no-till adoption may be influenced by artificial supports, this may reclassify potential farmers from opportunists. In this regard, Progress (2012) points out that once a subsidy project is completed farmers can stop practicing direct seeding because they no longer receive artificial incentives. 


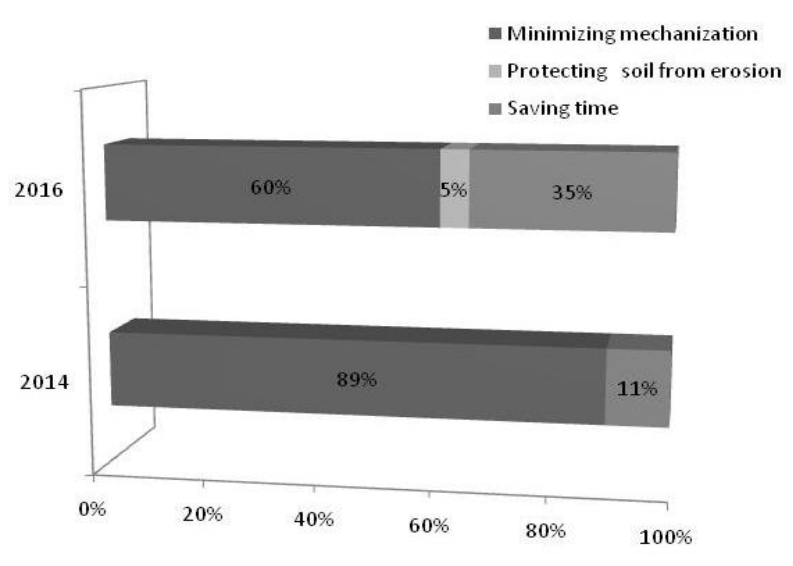

Fig. 5 Evolution of the main reasons for adopting no-till between 2014 and 2016

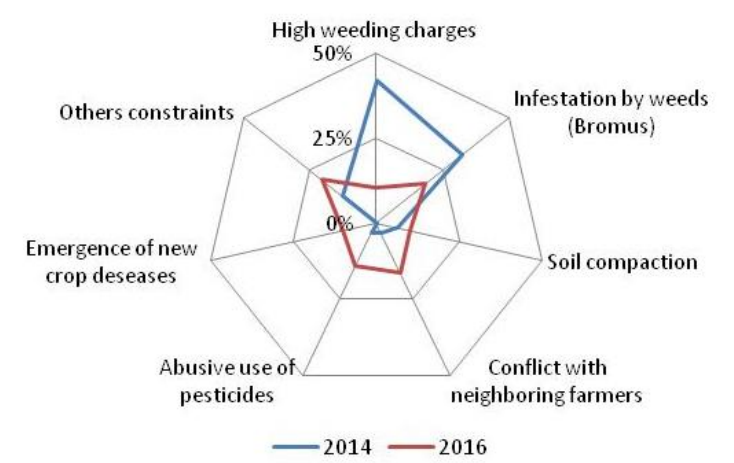

Fig. 6 Major constraints affecting no-till adoption in 2014 and 2016

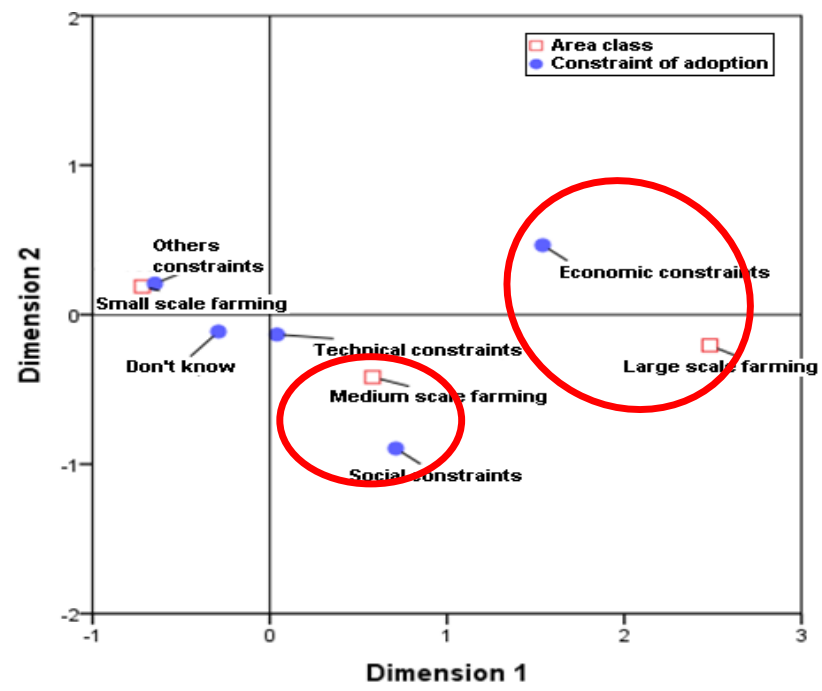

Fig. 7 Categorization of no-till constrains according the scale farming

Reasons for adopting no-till: In 2014, the survey showed that $89 \%$ of farmers considered that the decrease in mechanization is the most plausible reason for adopting no-till. However, in 2016, only $60 \%$ of them still believe in this reason (Fig. 5). According to Carof (2006), Aibar (2006) and Almaric et al., (2008) the abandonment of conventional plowing saves time, reduces the costs of mechanization and reduces also the cost of fuel.
The second motivating factor for adopting no-till is saving time of labor, in 2014, $11 \%$ of farmers thought that working time would be reduced in no-till system. However, in 2016, the rate of farmers who consider that no-till will save time of labor reaches $35 \%$. This result is due to the no-till experience gained recently by adoptive farmers, who are finally able to rank their priorities and choose the factors that are appropriate for them. According to Raunet et al., (1998) the suppression of plowing can facilitate cultural operations by saving time and allowing flexibility to farmers. In 2016, a slice of 5\% of farmers began to feel the importance of protecting their soil against erosion by adopting no-till.

Constraints of adopting no-till: Like any agricultural technique, no-till presents constraints that may compromise its adoption, the most observed constraints are classified on the basis of socioeconomic and technical aspects (Fig. 6).

\section{Economic Constraints}

- Necessity of acquiring a powerful tractor: No-till seeder is too heavy, it weighs between 2300 and 2500 $\mathrm{kg}$, so it needs a powerful tractor with more than 100 horsepower to be managed. Indeed, the majority of local farmers own medium power tractors (68 hp), therefore, this lack of mechanical power could compromise no-till adoption.

- Negative impact on the yield performance: During the early years of no-till experience, yield may drop because of the lack of mastery, regarding weed control and the incompatibility of no-till driller to the nature of soils. Consequently, some farmers do not accept to engage in this experience or endure the likely failure.

- High weeding charges: Many farmers considered that treatment costs weigh negatively on the adoption of no-till, where 13 farmers raised this constraint during 2014, whereas in 2016 only 5 farmers had evoked this constraint. That may be explained by the shift of farmers on other weed control alternatives such as rotation.

\section{Social Constraints}

Conflict with the farmer's neighborhood: It should be noted that no-till is a technique that aims to reabsorb the annual fallow, which may cause pressure on sheep's pasture areas. The rate of conflict with the neighborhood is increasing between the two years from 1 to 8 . Bensaid (2011) points out that the introduction of no-till technology could lead to competition between cereals and sheep farming. Locally, sheep farming has a social value and is well integrated with cereal practices. Thus, the introduction of new technologies should take into account the preservation of local agriculture criteria.

\section{Technical Constraints}

- Soil compaction: No-tillage gives the soil more stable structure and contributes to increase soil organic matter (Yin, 2008). Soil compaction would be reduced after a few years of practice. Farmers who considered that no-till increase soil compaction made their judgment on the basis of a short period of experience. 
- Lack of agricultural extension: The lack of information concerning the mastery of the technique and the handling of the no-till seeder represent an impediment for the no-till adoption. So many efforts should be provided also in the context of the sensitization towards the emergence of some pathogens and weeds which are likely to harm crops.

- Infestation by weeds: This constraint was too remarkable in the survey; it was relatively stable during the two years. This parameter is increasingly taken into account in rainfed farms, where the emergence of bromus species is a real challenge. Some studies indicated that the problem of the no-till cropping is the infestation by weeds, as outlined by Pèrez (1998) in Aibar (2006) noting that (Bromus ssp.), Lolium rigidum, Avena ssp and Alopecurus myosuroides could represent a serious problem for direct seeding.

- Emergence of new crop diseases. During 2016, 5 farmers raised this constraint; this is probably due to keeping stubble residues on the surface, thus encouraging the emergence of fungal pathogens, it is recommended to monitor the origin of these diseases with appropriate treatments.

- Abusive use of pesticides. Farmers who raised this constraint increased from 1 to 7 between the two years. That said the problem has economic, technical and health interests. The use of glyphosate animates more and more the controversy. In fact, repeated use of the same herbicide has resulted in resistance for some weeds. Glyphosate has become ubiquitous in ecosystems, affecting aquatic and terrestrial organisms and creating health problems in human populations (Morin, 2009). The development of these techniques has been accompanied by an increasing use of herbicides necessary for controlling the development of weeds which is no longer assured in part by agronomic techniques. Conservation systems are therefore efficient, but at high costs of chemical inputs, then the farmer should not be penalized by having to pay higher chemical expenses (William, 1997).

\section{Association Between the Scale Farming and Constraints of Adoption}

In order to summarize the understanding of the no-till adoption, all the observed constraints were pooled into three categories of constraints as shown above namely: social, economic and technical categories. Through an MCA including classes of area and categories of constraints as effective variables, results showed a strong association between economic constraints and large scale farming, while farms with medium scale farming were suffering from social constraints, however, the technical constraints were common for all the farms. The small scale farming presented some unusual constraints that are not frequently raised in the survey, furthermore some of small farms have not yet been confronted to any constraint (Fig. 7).

\section{Conclusion}

Although the technique of no-till has not yet proven its direct impact on yield crops in whole area and given the limited period of the study; the system showed some positive evolutions which would be appreciated; namely the reduction of time labor within the farm, this allowed farmers to diversify their activities and therefore improve their households incomes. Nevertheless, no-till could be confronted technical and agronomic constraints such as high cost of weed control and the proliferation of bromus.sp, which is one of the major challenges of direct seeding in the area of study. Results indicated that livestock system production is mainly based on sheep breeding; this one is influenced by no-till practices and can in turn inhibit its adoption. Between 2014 and 2016, results showed an increase of no-till area, while the recorded yields have evolved in some farms. On the other hand, the number of farmers practicing no-till has dropped by $71 \%$, a part of them are opportunists, they only want to take advantage of the incentives provided by the program, some of them really has hindrances to adopt direct seeding because of the lack of no-till seeder. It should be noted that farms that have kept the no-till practice are those that have recorded good economic performance and are those that have proper no-till seeder and are those that have high technical skills manager. The perspectives of the work are promising and require a rigorous follow-up; extension of such techniques should base on targeted farmers with specific criteria, namely a high economic performance of the farm, a high level of agricultural training and a good personal motivation.

\section{Acknowledgments}

This work is part of CANA project, kind thanks are presented to The Australian Center for International Agricultural Research (ACIAR), The International Center for Agricultural Research in the Dry Area (ICARDA) and the Master students: BENMAKHLOUF Amina and BOUCHAMA Sabrina.

\section{References}

Aibar J. 2006. La lutte contre les mauvaises herbes pour les céréales en semis direct: Principaux problèmes. In 'Actes des troisièmes rencontres méditerranéennes du Semis Direct'. Options méditerranéennes, série A, $69: 19-26$.

Almaric N, Brezillon M, Faiq CRE, Schroeder M, Tite A. 2008. La vulgarisation de l'agro-écologie: de la théorie au terrain. Octobre 2008 Projet INP-ENSAT/Solagro. pp 1-4.

BenSaid S. 2011. Evolution des caractéristiques des chaumes dans des parcelles conduites en semis direct et pâturées par des ovins. In: Bernués A. (ed.), Boutonnet J.P. (ed.), Casasús I. (ed.), Chentouf M. (ed.), Gabiña D. (ed.), Joy M. (ed.), López-Francos A. (ed.), Morand-Fehr P. (ed.), Pacheco F. (ed.). Economic, social and environmental sustainability in sheep and goat production systems Zaragoza: CIHEAM /FAO / CITA-DGA, 2011. p.335-339. (Options Méditerranéennes: Série A. Séminaires Méditerranéens; $\mathrm{N}^{\circ} 100$ ).

Ben-Salem H, Zaibet L, Ben-Hammouda M. 2006. Perspectives de l'adoption du semis direct en Tunisie: Une approche économique. Options Méditerranéennes, Série A, 69: pp 6975. 
Berranen H. 2007. La Formation agricole en Algérie: Problématique et prises en charge des nouveaux besoins. Premières rencontres euro-méditerranéennes de l'enseignement agricole public. Du 15 au 17 décembre 2007. Saint-Rémy-de-Provence. France.

Boiffin J, Malezieux E and Picard D. 2001. Cropping systems for the future. Crop Science: Progress and Prospects. CABI Publishing, Oxon (UK), pp. 261-280.

Carof M. 2006. Fonctionnement des peuplements en semis direct associant le blé tendre d'hiver (Triticum aestivum L.) à différentes plantes de couverture en climat tempéré. Thèse présentée pour l'obtention du titre de Docteur de l'Institut National Agronomique, Paris, Grignon. 115 p.

Chervet A, Ramseier L, Sturny W.G and Tschannen S. 2005. Comparaison du semis direct et du labour pendant 10 ans. Revue Suisse Agric. 37 (6): 249-256.

Djermoun A. 2009. La production des céréales en Algérie: Les principales caractéristiques. Nature and Technology, Juin, 01: 45-53

Escribano J. 2006. Étude des effets de l'agriculture de conservation par rapport à l'agriculture traditionnelle. Options Méditerranéennes, Série A, Numéro 69.pp 57-61.

Houmoura M, Sebaoune F. 2014. Etude de comportement des agricultures vis-à-vis de l'adoption du semis direct en zone semi-arides. Mémoire pour l'obtention de diplôme d'Ingénieur d'état en sciences agronomiques, Université Sétif $1,50 \mathrm{p}$.

Labad R, Hartani T. 2016. Analyse des performances de quelques exploitations agricoles céréalières en semis direct dans la wilaya de Sétif. Revue Agriculture. Numéro spécial 1: $78-81$.

Labreuche J, Souder L, Castillon P, Ouvry J. 2007. Evaluation des impacts environnementaux des Techniques Culturales Sans labour (TCSL) en France. Partie I: La pratique des TCSL en France. ADEME.

Masmoudi A. 2012. Etude de certains paramètres de durabilité des systèmes de production céréaliculture-élevage dans le contexte de l'intégration des techniques de l'agriculture de conservation. Thèse de Magister. UFASétif. 59p

Mokhneche S, El kolli N. 2013. Etude des pratiques agricoles dans la zone sud de la wilaya de Sétif, Mémoire d'ingénieur d'Etat en sciences agronomiques, UFAS1.

Morin O. 2009. Séquelles sociales et écologiques du soja transgénique en Argentine. Maîtrise en biologie. Université de Sherbrooke. Canada

Mrabet R. 2000. Differential response of wheat to tillage management systems in a semi-arid area of Morocco. Field Crop Research, 66:165-174.
Mrabet R. 2001. Le semis direct: une technologie avancée pour une agriculture durable au Maroc. MADREF - DERD. $\mathrm{N}^{\circ}$ 76, 4p. http://agriculture.ovh.org.

Mrabet R. 2010. Climate change and carbon sequestration in the Mediterranean bassin: contribution of no tillage systems. Les actes des 4ème Rencontres Méditerranéennes du Semis Direct. Sétif Algérie 3, 4, 5 mai 2010. $\mathrm{N}^{\circ}$ spécial revue Recherche agronomique, 106-126.

Pèrez B. 1998. Encuesta regional sobre la siembra directa. Informaciones TĖcnicas, No. 52. Departamento de Agricultura del Gobierno de AragÛn, 8 pp.

Progress HN. 2012. Factors Influencing Adoption and Area under Conservation Agriculture: A Mixed Methods Approach, Sustainable Agriculture Research; 1(2):27-40, http://dx.doi.org/10.5539/sar.v1n2p27

Raunet M, Seguy L, Fovet Rabots C. 1998. Semis direct sur couverture végétale permanente du sol: de la technique au concept. Document obtenu sur le site Cirad du réseau http://agroecologie.cirad.fr. 23-28 mars 1998, Anae, Cirad, Fafala, Fifamanor, Fofifa, Tala. Montpellier, France, Cirad, collection Colloques, $658 \mathrm{p}$.

Rouabhi A. 2014. Implications des changements climatiques dans l'agriculture et le développement durable : Cas des hautes plaines Sétifiennes. Thèse de Doctorat, Université Ferhat ABBAS, Sétif 1, (Algérie), 205p.

Rouabhi A, Hafsi M, Kebiche M. 2014. Assessment of the farming transformation in a rural region of Sétif province in Algeria. New Medit N²/2014. 38-46.

Rouabhi A, Mekhlouf A, Mokhneche S, Elkolli N. 2016. Farming transitions under Socio-economic and climatic constraints in the southern part of Sétif, Algeria. -JAEID 2016, 110 (1): 139 - 153. DOI: 10.12895/jaeid.20161.429.

William RH. 1997. Farmland Leasing: Crop-Share Leases and No-Till. Farm Business Management Handbook. FBM0207. Illinois university.

Yin C. 2008. Increasing soil organic carbon of agricultural land. PRIMEFACT 735. www.dpi.nsw.gov.au/primefact (website visited in Dec 20th 2016)

Zaghouane O, Abdellaoui Z, Houassine D. 2006. Quelles perspectives pour l'agriculture de conservation dans les zones céréalières en conditions algériennes? Options Méditerranéennes, Série A, 69: 183-187.

Zoghbi S. 1992. La vulgarisation de la culture du pois chiche dans la wilaya de Sétif. Cahiers Options Méditerranéennes, Vol. 2, n 1 